\title{
Present and potential future critical source areas of nonpoint source pollution: a case of the Nakdong River watershed, South Korea
}

\author{
Mijin Seo ${ }^{1}$ (D) · Joonghyeok $\mathrm{Heo}^{2} \cdot$ Yongseok Kim $^{1}$ (D)
}

Received: 6 August 2020 / Accepted: 10 February 2021 / Published online: 20 April 2021

(C) The Author(s) 2021

\begin{abstract}
Identifying critical source areas (CSAs) is the first step to effectively managing nonpoint source (NPS) pollution. Increasing variability in climate can affect identification of CSAs. In this study, we identified present and future CSAs of NPS pollution in the Nakdong River watershed and examined how climate change will influence the identification of CSAs. Nine NPS pollutionrelated factors affecting the watershed environment and water quality were considered. These factors were rescaled through a min-max normalization to propose an index system that ranks basins based on the sensitivity of basins to climate change on identifying CSAs. For analyses, past rainfall was replaced with future rainfall under two RCP scenarios, RCP 2.6 and RCP 8.5. Results showed insignificant differences in the spatial distribution of CSAs between the present and the future and between the future scenarios. Basins that are on or adjacent to the Nakdong River mainstream were mainly identified as CSAs, in addition to many basins of the Geumho and Nam rivers. Highly ranked CSAs including the level 1 CSAs, were mainly distributed in the mid- and downstream areas of the Nakdong River, indicating high need of NPS pollution management. This study can provide a foundation for the effective management of NPS pollution in the present and the future.
\end{abstract}

Keywords Nakdong River watershed $\cdot$ NPS pollution $\cdot$ CSAs $\cdot$ Past rainfall $\cdot$ Climate change $\cdot$ RCP

\section{Introduction}

Nonpoint source (NPS) pollution by diffuse sources of pollutants on the landscape is difficult to manage due to the nature of diffuse sources presenting large spatial and temporal variabilities. The management of NPS pollution has however become essential in South Korea due to growing proportion of NPS pollution over the total water pollution (Kang et al. 2014). Managing land areas to control NPS pollution requires substantial efforts and large costs (Kang et al. 2013). To effectively manage NPS pollution, critical source areas (CSAs) susceptible to NPS pollution should be first to be identified and systematically managed. The identification of CSAs of NPS pollution

Responsible Editor: Xianliang Yi

Yongseok Kim nierkys@korea.kr

1 Nakdong River Environment Research Center, National Institute of Environmental Research, 24-11, Gukgasandan-daero 52, Daegu 43008, South Korea

2 University of Texas-Permian Basin, 4901 E. University Blvd., Odessa, TX 79762, USA has been studied using various methods: laboratory experiments (Doppler et al. 2014; Lucci et al. 2012), water quality change analysis (Kang et al. 2013), correlation analysis (Kal et al. 2019), overlay analysis using the geographic information system (GIS) (Orlikowski et al. 2011; Park et al. 2010), and analytic hierarchy process (AHP) involving expert surveys (Jang et al. 2012; Shin et al. 2007). Various models have been also used to identify areas in need of NPS pollution management (Dong et al. 2018; Ghebremichael et al. 2010; Liu et al. 2016; Niraula et al. 2012, 2013; Shang et al. 2012; Winchell et al. 2015; Yi et al. 2015; Zhuang et al. 2016). However, laboratory experiments are often limited in research scope and water quality monitoring studies are time-consuming and require a large workforce and costs (Lee et al. 2012; Park et al. 2015). The AHP method has uncertainties associated with variable independence and hierarchy (Jang et al. 2012; Shin et al. 2007). Modeling approaches are often challenged by the difficulties in the composition of input data and long processing time (Jang et al. 2012; Munafo et al. 2005). Identifying CSAs using such complex and limited methods can delay the progress of NPS pollution management. A simple and parsimonious approach using NPS pollution-related factors can be an effective method for NPS pollution management. 
The Ministry of Environment (MOE) of South Korea provides governmental authority in managing CSAs of NPS pollution, which are defined as areas with (1) $>50 \%$ NPS pollution among watersheds not meeting water quality standards, (2) a population above one million, (3) industrial complexes, (4) NPS pollutants harming the environment, or (5) the necessity of geographical management (Article 54 of the Water Environment Conservation Act and Article 76 of the Enforcement Degree of the Water Environment Conservation Act). The Nakdong River watershed, the second largest watershed in South Korea, has the basins including Andong, Yangsan, and Kimhae cities which are identified as CSAs under the Articles 54 and 76. Other basins of the Nakdong River watershed have been proposed to be designated as CSAs through several studies performed by the MOE (Kim et al. 2012; MOE 2016a; Park et al. 2013, 2015). The Korea Environment Corporation (KECO) (2018) has also studied CSAs that are in need for the management of agricultural NPS pollution in the Nakdong River watershed. However, most of these studies targeted at large scale (whole peninsula of South Korea) or at micro scale (only several parts of a watershed) as the study area. The prioritization of CSAs can change depending on the spatial scope of the analysis. At large scale, high priorities of CSAs can be given to a certain watershed with many pollution factors such as a high ratio of impervious areas and high population density and potential CSAs in other watersheds can be excluded. At micro scale, it is difficult to figure out whether the selected study area has a higher priority than other areas. Because each watershed has different characteristics, selecting a target watershed with similar characteristics can lead to an appropriate identification of CSAs of NPS pollution in the watershed.

Studies of CSAs of NPS pollution often relied on past rainfall as a forcing term. However, rainfall variation due to climate change can lead to changes in the discharge characteristics of NPS pollutants (Seo et al. 2019a), which can affect changes in CSAs of NPS pollution. The Intergovernmental Panel on Climate Change established four Representative Concentration Pathways (RCP) climate change scenarios $(8.5 / 6.0 / 4.5 / 2.6)$, from high-concentration greenhouse gas emission scenario to mitigation scenario. Under the RCP system, the Korea Meteorological Administration (KMA) provides the global (135 $\mathrm{km}$ resolution), Korean Peninsula (12.5 $\mathrm{km}$ resolution), and South Korea (1 km resolution) future climate data until 2100. The National Institute of Meteorological Research (NIMR) (2012) predicted the increases of temperature and rainfall and the aggravation of climate change for the Korean Peninsula. Accordingly, studies have demonstrated the negative impact of climate change on NPS pollution in South Korea (Ahn et al. 2014; Han et al. 2017; Jang and Kim 2017). In this regard, identifying CSAs under climate change and preparing for changes in CSAs are necessary steps to an effective management of NPS pollution.
However, the impact of climate change was only considered in few studies of CSAs and most of them were modeling approaches (Liu et al. 2017; Renkenberger et al. 2016; Shrestha et al. 2019).

This study attempted to identify present and future CSAs and to examine spatial variability of CSAs under future climate scenarios in the Nakdong River watershed, South Korea. The CSAs where management should be prioritized were identified using a parsimonious method which utilizes NPS pollution-related factors to rank CSAs and to analyze spatial distributions of CSAs. The novel method can help policy makers effectively manage CSAs for NPS control against present and future climates.

\section{Materials and methods}

\section{Study area}

The watershed of the Nakdong River, the longest river in southeastern South Korea, covers an area of 23,384 $\mathrm{km}^{2}$. The Nakdong River watershed consists of 22 subbasins which are further split to 195 basins where a basin is the smallest unit (Fig. 1). Major tributaries (e.g., Banbyeon, Naeseong, Geumho, Nam, and Milyang) flow into the Nakdong River and water quality monitoring stations are operated in the tributaries and mainstream. The climate of the Nakdong River watershed is hot and humid in the summer and cold and dry in the winter. The annual rainfall is on average $1200 \mathrm{~mm}$ and approximately $60 \%$ of the total rainfall occurs during rainy season from June to September due to large seasonal variation.

\section{Data collection and build-up}

Various NPS pollution-related factors affecting the watershed and water quality environments were considered in the analysis. These factors were selected by referring to related studies (Kim et al. 2012, 2019; Lee et al. 2012; NRERC 2018; Orlikowski et al. 2011; Park et al. 2010). Nine factors were selected, that is, load factors (1) NPS pollution load per unit area, (2) residential/industrial NPS pollution load per unit area; water quality factors (3) mean water quality, (4) excess percentage of water quality standards, (5) water quality index; and watershed environment factors (6) impervious area, (7) soil slope, (8) topsoil type, (9) rainfall.

The loads (factors 1 and 2) were determined for each basin using estimated load data of biological oxygen demand (BOD), total nitrogen (TN), and total phosphorus (TP), based on the technical guidelines for Korean total maximum daily loads (TMDLs) (NIER 2019). The mean water quality (factor 3 ) and the excess percentage of water quality standards (factor 4) were determined for each basin using water quality data 


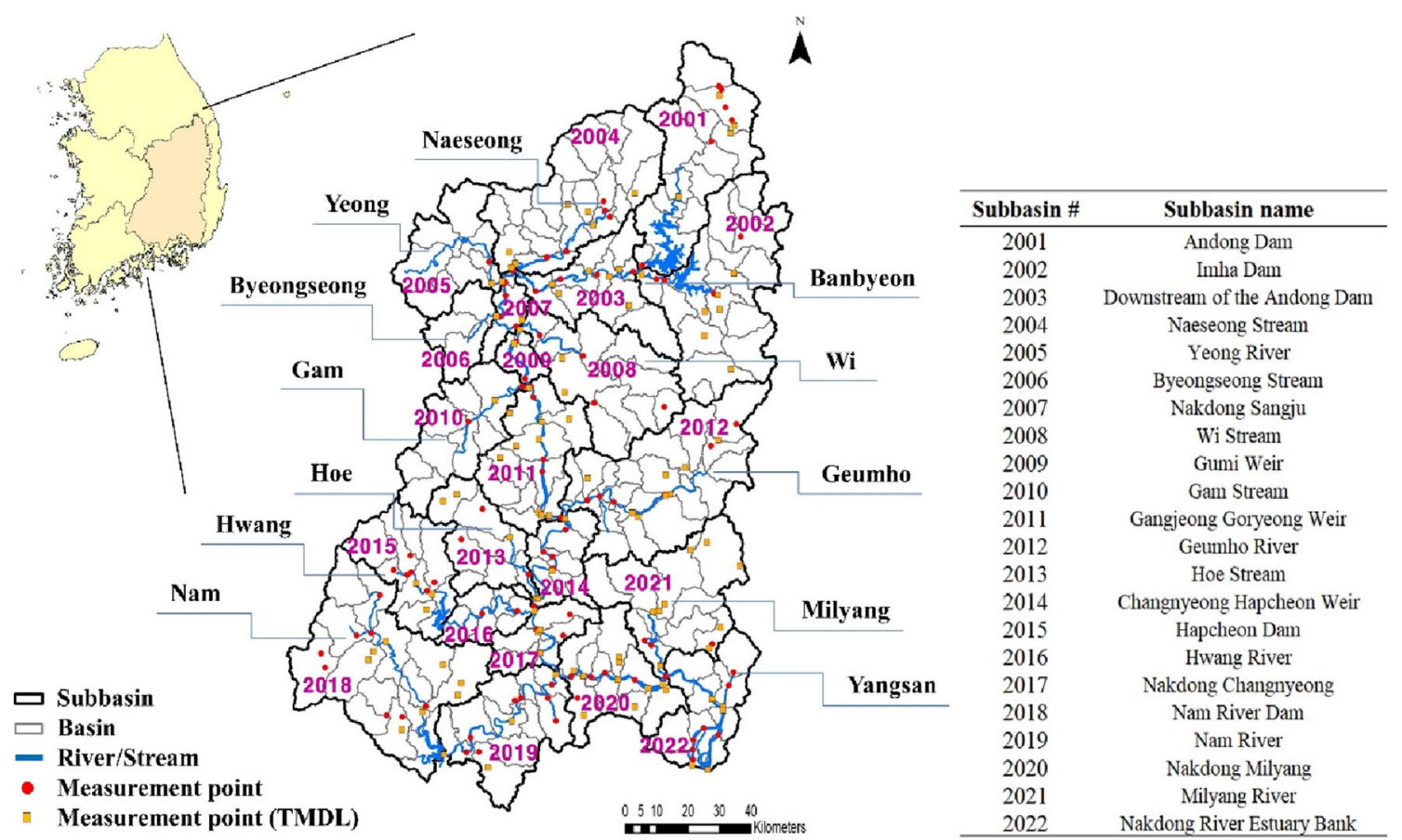

Fig. 1 Nakdong River watershed consisting of 22 subbasins and 195 basins. The first letter of each word of subbasin and basin names was capitalized in the study

including BOD, chemical oxygen demand (COD), TP, suspended solid (SS), and total organic carbon (TOC) at 253 monitoring stations in the Nakdong River watershed. The variables were chosen depending on the availability of data and the existence of water quality standards. The data were considered for rainy season (June to September) which can reflect the impact of NPS pollution and were obtained from the Water Environment Information System (http://water.nier.go.kr). The excess percentage of water quality standards for each basin was calculated from the difference between the mean water quality and water quality standards:

Excess percentage $(\%)=\frac{\left(V_{i}-V_{s}\right)}{V_{s}} \times 100$

where $\mathrm{V}_{\mathrm{i}}$ is the mean water quality of the basin $\mathrm{i}$, and $\mathrm{V}_{\mathrm{s}}$ is the water quality standards of the basin $i$. The water quality index (WQI; factor 5) is a water quality score that is used to classify various and complex water quality states. It is divided into five levels: satisfactory (80-100), adequate (60-79), normal (4059 ), cautious (20-39), and poor (0-19). The WQI was calculated for each basin as follows:

$\mathrm{WQI}=100-\sqrt{\frac{\left(F_{1}^{2}+F_{2}^{2}+F_{3}^{2}\right)}{3}}$

where $F_{1}, F_{2}$, and $F_{3}$ are obtained from the number, number of times, and degree of water quality variables not meeting standard values, respectively. More details can be found in the Real Time Water Quality Information System (http:// www.koreawqi.go.kr). For water quality factors, to ensure that basins without water quality monitoring stations were not excluded from the identification of CSAs, the mean values of their subbasins were applied to each basin (Kim et al. 2012).

The impervious area (factor 6) was determined using land cover data from the Environmental Geographic Information Service. The total area, including the urban areas and greenhouses in agricultural areas, was calculated for each basin. The soil slope (factor 7) and the topsoil type (factor 8) were determined using soil data from the Rural Development Administration. A steep slope can negatively affect water quality because more pollutants are discharged into the river due to soil losses. Thus, except for the slope of $60-100 \%$ including mountainous areas, the total area in the second steepest slope ranges (30-60\%) was calculated for each basin. Regarding the topsoil type, clay loam soils belonging to type D of the Natural Resources Conservation Service hydrologic soil groups (HSGs) exhibit the lowest infiltration and highest surface runoff among the four HSGs (MOE 2016b). The total area of clay loam and silty clay loam soils was estimated for each basin. The rainfall (factor 9) was determined using past and future rainfall data obtained from 24 weather stations of KMA in the Nakdong River watershed. Average annual rainfall was calculated for each weather station and the rainfall of each basin was then calculated via weighted mean using the Thiessen polygon method. To assess the variability of CSAs of NPS pollution due to future climate change, RCP 2.6, the best scenario in which the Earth can recover from the impact of human activities on its own, and 
$\mathrm{RCP} 8.5$, the worst scenario in which greenhouse gas emissions continue to occur, were considered as future scenarios. The Korean Peninsula (12.5 km resolution) rainfall data from 2021 to 2100 were processed for both scenarios. The nine factors mentioned above were determined using data available from 2008 to 2018 and most recently updated data.

\section{Analysis method}

The impact of NPS pollution on the 195 basins of the Nakdong River watershed was analyzed by normalizing each factor. Normalization is a method that can be used to evaluate factors on the same basis by scaling each factor to have values between 0 and 1 . The values of each factor were normalized with the minmax method and expressed as percentages (I) in Eq. (3). A higher percentage indicates a higher impact of NPS pollution. The final index (FI) was calculated for each basin based on the sum of factors multiplied by an equal weight as Eq. (4). The CSAs were identified by ranking the FI values of basins.

$\mathrm{I}=\frac{\left(V_{i}-V_{\min }\right)}{\left(V_{\max }-V_{\min }\right)} \times 100$

$\mathrm{FI}=$ factor $1 \times \mathrm{w} 1+$ factor $2 \times \mathrm{w} 2+\cdots+$ factor $9 \times \mathrm{w} 9$

where $\mathrm{V}_{\mathrm{i}}$ is the value of the basin $\mathrm{i}, \mathrm{V}_{\min }$ and $\mathrm{V}_{\max }$ are the minimum and maximum values among all 195 basins, respectively, and $w$ is the weight of each factor. The method using NPS pollution-related factors to identify CSAs can be easily applied to large watersheds and was utilized in several studies (Jang et al. 2012; Kim et al. 2012, 2019; Lee et al. 2012). Among the 195 basins, the top 30\% (ranks 1-59) in high need of NPS pollution management were identified. The identified CSAs were further divided into three subgroups to analyze the rankings: level 1 (1\%-10\%; ranks 1-20), level 2 (11\%-20\%; ranks 21-39), and level 3 (21\%-30\%; ranks 40-59). Results were obtained for BOD and TP and for total nonpoint (TNP), which means the average of considered water quality variables. The present and future CSAs were determined by applying past and future rainfall data, respectively, under the same factor conditions. For the present results, the reliability of the identified CSAs was evaluated in comparison with CSAs in the Nakdong River watershed that were reported by the MOE and KECO, as mentioned in the "Introduction" section.

\section{Load duration curve analysis}

Load duration curve (LDC) analysis can be used to identify areas that require NPS pollution management based on the comparison between the target and measured loads estimated using target and measured water quality and flow data. Related studies have shown that LDC analysis is suitable for the identification of CSAs of NPS pollution (Jang et al. 2018; Kim 2014; Park et al. 2015, 2017). Park et al. (2015) used
LDC analysis to compensate for temporal variations of flow and water quality in the identification of CSAs. This study also used LDC analysis to assess the reliability of the identified CSAs.

The LDC was drawn by exclusively using Korean TMDL monitoring stations that measure both water quality and flow. The MOE has been operating a total of 102 monitoring stations in the Nakdong River watershed (Fig. 1); the target water quality regarding BOD and TP has been set and systematically managed under the Korean TMDL program. The LDC was drawn using BOD, TP, and flow data collected at each of the 102 monitoring stations from 2008 to 2018 . The flow intervals $(x$-axis) of the LDC are divided into high flows $(0-10 \%)$, moist conditions (10-40\%), mid-range flows (40-60\%), dry conditions (60-90\%), and low flows (90-100\%), where each interval indicates different pollutant properties. The United States Environmental Protection Agency US EPA (2007) reported that the high flow and moist condition intervals generally reflect the impact of NPS pollution. Jung et al. (2011) also mentioned that the deterioration of the water quality in the intervals above moist conditions could be explained with NPS pollution. In LDC analysis, the water quality is deemed unsatisfying if the measured load exceeds the target load by more than $50 \%$ for each interval. In this study, the LDC was analyzed for the excess rates in the high flow and moist condition intervals. Basins including unsatisfying monitoring stations were identified and the top 10\% (ranks 1-10) basins in high need of NPS pollution management were identified by ranking normalized excess rates. The basins were analyzed in comparison with the present CSAs.

\section{Results and discussion}

\section{Factor analysis}

The impact of each factor on NPS pollution in the Nakdong River watershed was examined by ranking normalized values (Fig. 2). The NPS pollution load accounted for $70-80 \%$ of the total load. The land and livestock pollution load accounted for 98-99\% of the NPS pollution load, with a greater contribution by lands than by livestock. The NPS pollution load was generally high in the basins of the Naeseong and Byeongseong streams, Geumho River, and downstream of the Nakdong River. For the residential/industrial NPS pollution load, the basins of the Nam and Yeong rivers were also found to be high. The water quality tended to be high in the mid- and downstream basins of the Nakdong River including the Geumho and Nam rivers. For TP, the basins of the Byeongseong and Gam streams also showed high tendencies. The WQI indicated a trend similar to the water quality. On the other hand, the excess percentage of water quality standards was generally high in the upstream basins. Within the Geumho River and Changnyeong Hapcheon 

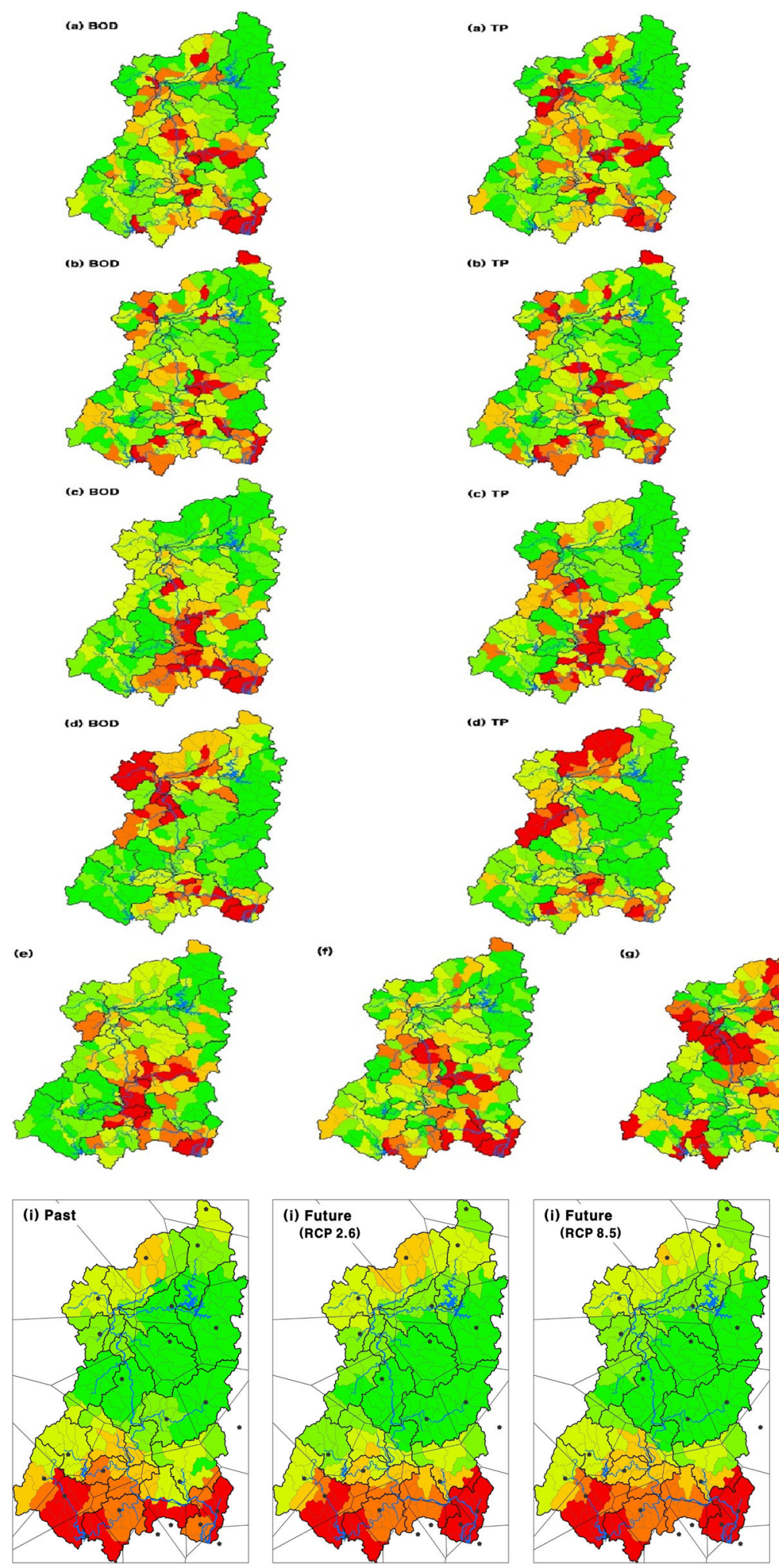

Fig. 2 Influence of each factor on NPS pollution in the Nakdong River watershed. a NPS pollution load per unit area, $\mathbf{b}$ residential/industrial NPS pollution load per unit area, $\mathbf{c}$ mean water quality, $\mathbf{d}$ excess percentage of

Weir subbasins with the lowest standards, only the Jincheon Stream basin did not meet the water quality standards.
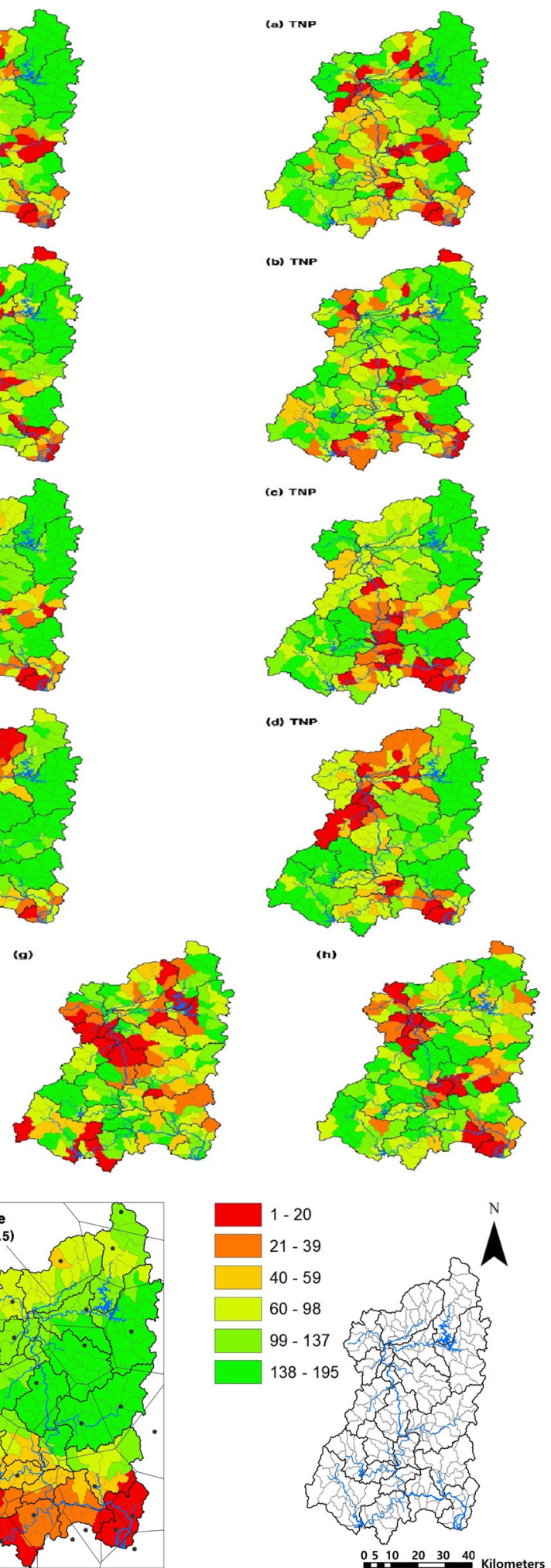

water quality standards, $\mathbf{e}$ water quality index, $\mathbf{f}$ impervious area, $\mathbf{g}$ soil slope (30-60\%), $\mathbf{h}$ topsoil type (clay loam), and $\mathbf{i}$ rainfall. Left, middle, and right figures from (a) to (d) mean BOD, TP, and TNP, respectively

The Nakdong River watershed was comprised of mountainous areas $(67.2 \%)$, agricultural areas $(22.7 \%)$, urban areas 


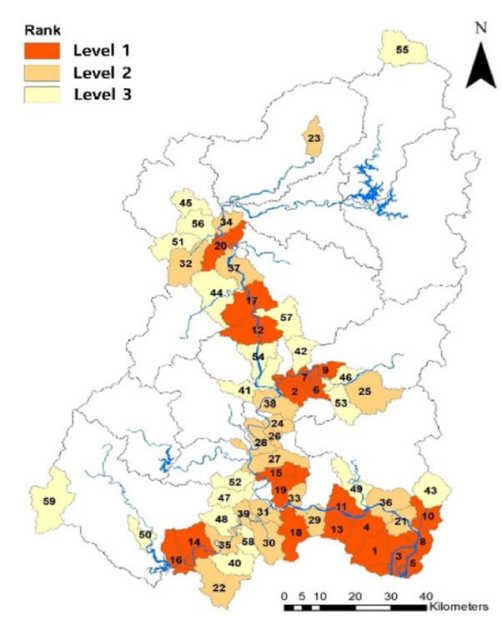

(a) BOD

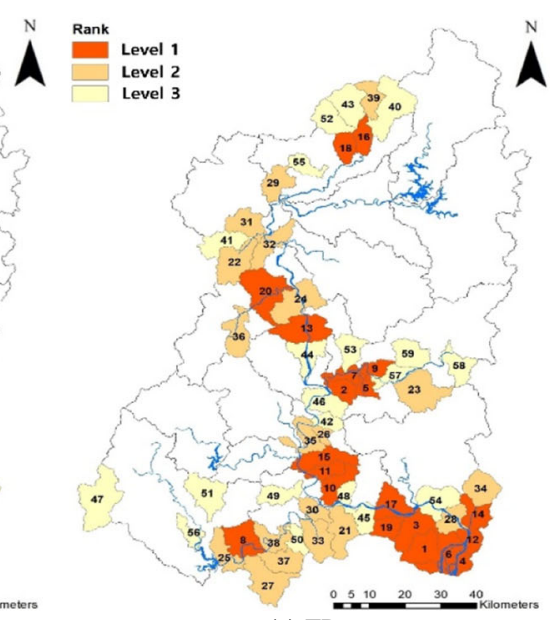

(a) TP

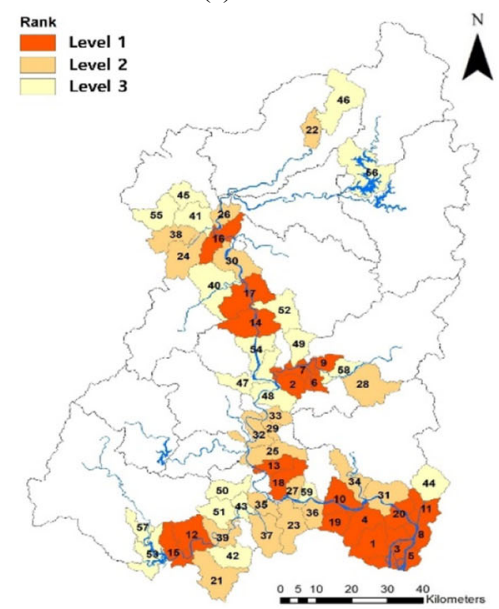

(b) $\mathrm{BOD}$

A

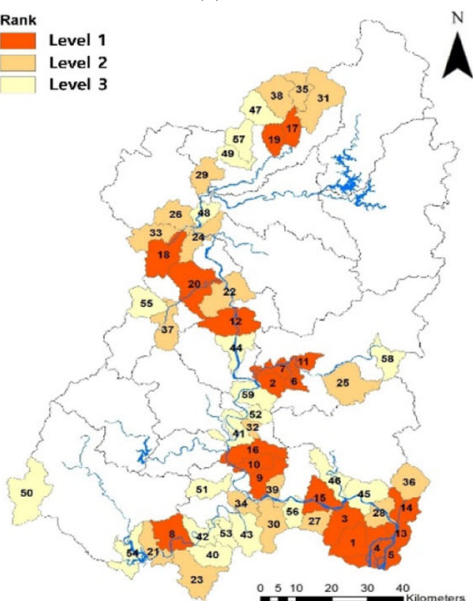

(b) $\mathrm{TP}$

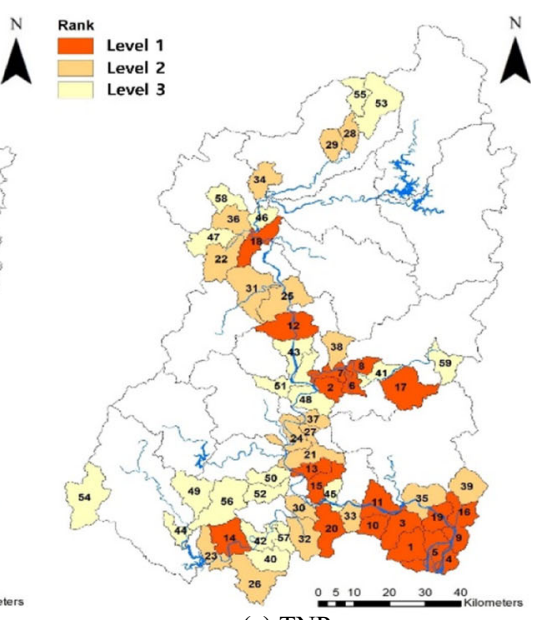

(a) TNP

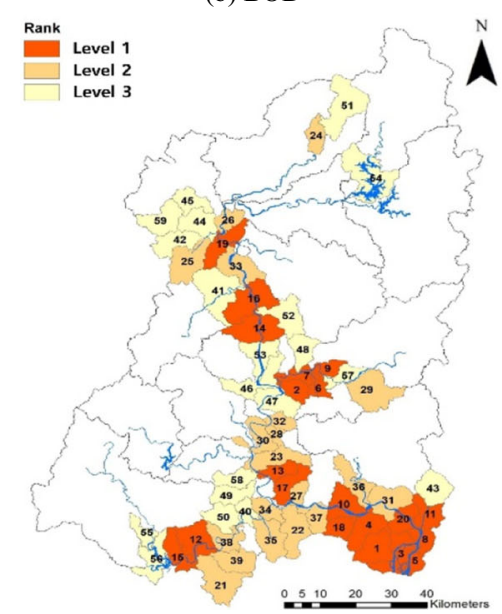

(c) BOD
$\bigwedge^{N \quad \begin{array}{l}\text { Rank } \\ \text { Level } 1 \\ \text { Level } 2 \\ \text { Level } 3\end{array}}$

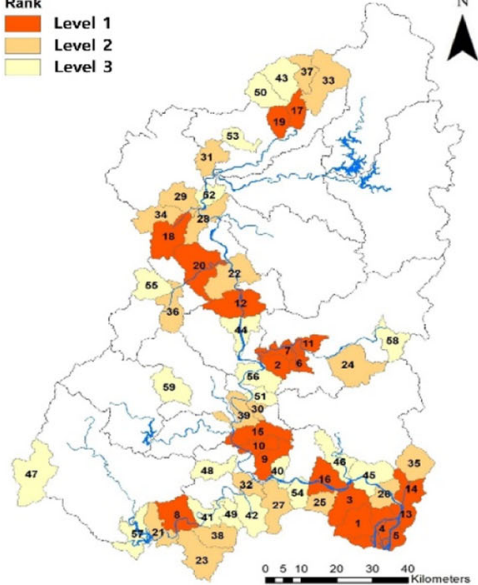

(c) TP

$\bigwedge_{\substack{N \\ \text { Rank }}}^{\substack{\text { Level } 1 \\ \text { Level } 2 \\ \text { Level } 3}}$

\section{A}

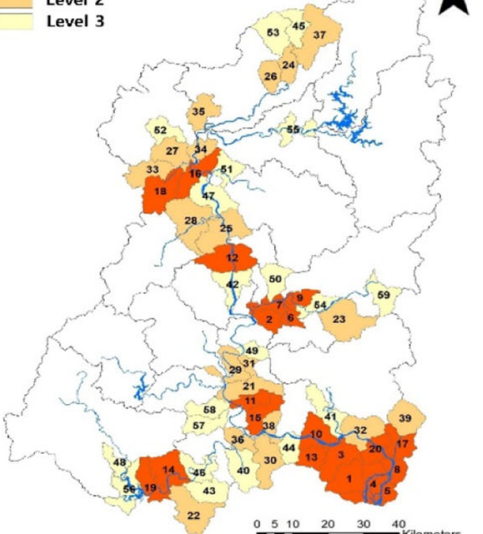

(b) TNP

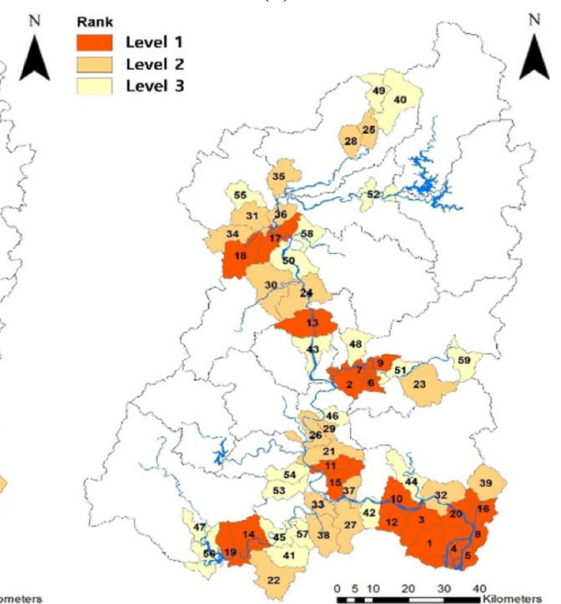

(c) TNP

Fig. 3 Results of the CSA identification for each variable in the present (a) and the future (b RCP2.6, $\mathbf{c}$ RCP8.5). The number and color of each basin indicate its rank and subgroup, respectively. Left, middle, and right figures from (a) to (c) mean BOD, TP, and TNP, respectively

(4.5\%), and other landuses (grasslands, wetlands, bare lands, and water bodies; $5.6 \%$ ). Greenhouses accounted for $2.3 \%$ of the agricultural area and the impervious area susceptible to NPS pollution was $5.0 \%$ of the total area. The impervious area was generally high in the mid- and downstream basins of the Nakdong River including the Geumho and Nam rivers. The steepest slope ratio was $60-100 \%$ (36.5\% of the watershed), followed by the $30-60 \%$ slope ( $23.6 \%$ of the watershed). Basins with the 30-60\% slope were mainly found in the upper- and midstream areas of the Nakdong River. More than 90\% of the Nakdong River watershed had silty loam, loam, and sandy loam soil types. Clay loam soils accounted for only 
Table 1 Rankings of CSAs (basins) for each variable in the present

\begin{tabular}{|c|c|c|c|c|}
\hline Rank & Subgroup & BOD & $\mathrm{TP}$ & TNP \\
\hline 1 & \multirow[t]{20}{*}{ Level 1} & Joman River ${ }^{\mathrm{a}}$ & Joman River ${ }^{\mathrm{a}}$ & Joman River ${ }^{\mathrm{a}}$ \\
\hline 2 & & Jincheon Stream $^{\mathrm{a}}$ & Jincheon Stream $^{\mathrm{a}}$ & Jincheon Stream ${ }^{\mathrm{a}}$ \\
\hline 3 & & West Nakdong River ${ }^{a}$ & Hwapo Stream ${ }^{\mathrm{a}}$ & Hwapo Stream ${ }^{\mathrm{a}}$ \\
\hline 4 & & Hwapo Stream ${ }^{a}$ & Nakdong River Estuary Bank ${ }^{\mathrm{a}}$ & Nakdong River Estuary Bank ${ }^{\mathrm{a}}$ \\
\hline 5 & & Nakdong River Estuary Bank ${ }^{\mathrm{a}}$ & Downstream of the Shin Stream ${ }^{a}$ & West Nakdong River ${ }^{\mathrm{a}}$ \\
\hline 6 & & Downstream of the Shin Stream ${ }^{a}$ & West Nakdong River ${ }^{\mathrm{a}}$ & Downstream of the Shin Stream ${ }^{a}$ \\
\hline 7 & & Downstream of the Geumho River & Downstream of the Geumho River & Downstream of the Geumho River \\
\hline 8 & & Gupo Water Level Gauging Station ${ }^{\mathrm{a}}$ & After Merging of the Banseong Stream & Midstream of the Geumho River \\
\hline 9 & & Midstream of the Geumho River & Midstream of the Geumho River & Gupo Water Level Gauging Station ${ }^{\mathrm{a}}$ \\
\hline 10 & & Downstream of the Yangsan Stream ${ }^{\mathrm{a}}$ & Gyeseong Stream $^{\mathrm{a}}$ & Jucheon River \\
\hline 11 & & Before Merging of the Milyang River & Masuwon Water Level Gauging Station ${ }^{\mathrm{a}}$ & Before Merging of the Milyang River \\
\hline 12 & & Chilgok Weir ${ }^{\mathrm{a}}$ & Gupo Water Level Gauging Station ${ }^{\mathrm{a}}$ & Chilgok Weir $^{\mathrm{a}}$ \\
\hline 13 & & Jucheon River & Chilgok Weir $^{\mathrm{a}}$ & Masuwon Water Level Gauging Station ${ }^{\mathrm{a}}$ \\
\hline 14 & & After Merging of the Banseong Stream & Downstream of the Yangsan Stream ${ }^{a}$ & After Merging of the Banseong Stream \\
\hline 15 & & Masuwon Water Level Gauging Station ${ }^{\mathrm{a}}$ & Jeokpogyo Water Level Gauging Station & Gyeseong Stream $^{\mathrm{a}}$ \\
\hline 16 & & Before Merging of the Yeongcheon River & Downstream of the Seo Stream ${ }^{a}$ & Downstream of the Yangsan Stream ${ }^{a}$ \\
\hline 17 & & After Merging of the Han Stream & Before Merging of the Milyang River & Omok Stream ${ }^{\mathrm{a}}$ \\
\hline 18 & & Gwangryeo Stream $^{\mathrm{a}}$ & Okgye Stream $^{\mathrm{a}}$ & Before Merging of the Wi Stream \\
\hline 19 & & Gyeseong Stream $^{\mathrm{a}}$ & Jucheon River & Wolchon Water Level Gauging Station \\
\hline 20 & & Before Merging of the Wi Stream & Downstream of the Gam Stream ${ }^{a}$ & Gwangryeo Stream $^{\mathrm{a}}$ \\
\hline 21 & \multirow[t]{19}{*}{ Level 2} & Wolchon Water Level Gauging Station & Gwangryeo Stream $^{\mathrm{a}}$ & Jeokpogyo Water Level Gauging Station \\
\hline 22 & & Yeongcheon River & Upstream of the Byeongseong Stream $^{\mathrm{a}}$ & Upstream of the Byeongseong Stream $^{\mathrm{a}}$ \\
\hline 23 & & Downstream of the Seo Stream ${ }^{a}$ & Omok Stream $^{\mathrm{a}}$ & Before Merging of the Yeongcheon River \\
\hline 24 & & Hyeonpung Water Level Gauging Station & After Merging of the Han Stream & Changnyeong Hapcheon Weir ${ }^{\mathrm{a}}$ \\
\hline 25 & & Omok Stream $^{\mathrm{a}}$ & Before Merging of the Yeongcheon River & After Merging of the Han Stream \\
\hline 26 & & Cha Stream & Cha Stream & Yeongcheon River \\
\hline 27 & & Jeokpogyo Water Level Gauging Station & Yeongcheon River & Cha Stream \\
\hline 28 & & Changnyeong Hapcheon Weir ${ }^{\mathrm{a}}$ & Wolchon Water Level Gauging Station & Downstream of the Seo Stream ${ }^{a}$ \\
\hline 29 & & After Merging of the Shin Stream & Geum Stream $^{\mathrm{a}}$ & Okgye Stream $^{\mathrm{a}}$ \\
\hline 30 & & Haman Stream & Downstream of the Nam River & Downstream of the Nam River \\
\hline 31 & & Downstream of the Nam River & Downstream of the Byeongseong Stream ${ }^{\mathrm{a}}$ & Downstream of the Gam Stream ${ }^{\mathrm{a}}$ \\
\hline 32 & & Upstream of the Byeongseong Stream $^{\mathrm{a}}$ & Before Merging of the Wi Stream & Haman Stream \\
\hline 33 & & Haman Changnyeong Weir & Haman Stream & After Merging of the Shin Stream \\
\hline 34 & & Sangju Weir & Upstream of the Yangsan Stream ${ }^{a}$ & Geum Stream $^{\mathrm{a}}$ \\
\hline 35 & & Jeongam Water Level Gauging Station & Changnyeong Hapcheon Weir ${ }^{\mathrm{a}}$ & Before Merging of the Wondong Stream \\
\hline 36 & & Before Merging of the Wondong Stream & Gimcheon Water Level Gauging Station & Downstream of the Byeongseong Stream ${ }^{a}$ \\
\hline 37 & & Gumi Weir & Banseong Stream & Hyeonpung Water Level Gauging Station \\
\hline 38 & & $\begin{array}{l}\text { Goryeonggyo Water Level Gauging } \\
\text { Station }\end{array}$ & Jeongam Water Level Gauging Station & Palgeo Stream \\
\hline 39 & & Before Merging of the Haman Stream & Nakhwaam Stream & Upstream of the Yangsan Stream ${ }^{a}$ \\
\hline 40 & \multirow[t]{8}{*}{ Level 3} & Banseong Stream & Upstream of the Naeseong Stream $^{\mathrm{a}}$ & Banseong Stream \\
\hline 41 & & Gangjeong Goryeong Weir & Buk Stream & Dongchon Water Level Gauging Station ${ }^{\mathrm{a}}$ \\
\hline 42 & & Palgeo Stream & Hyeonpung Water Level Gauging Station & Jeongam Water Level Gauging Station \\
\hline 43 & & Upstream of the Yangsan Stream $^{\mathrm{a}}$ & Jukgye Stream & Seongju Water Level Gauging Station \\
\hline 44 & & Downstream of the Gam Stream ${ }^{a}$ & Seongju Water Level Gauging Station & Upstream of the Nam River Dam \\
\hline 45 & & Downstream of the Ian Stream & After Merging of the Shin Stream & Haman Changnyeong Weir \\
\hline 46 & & Dongchon Water Level Gauging Station ${ }^{\mathrm{a}}$ & $\begin{array}{l}\text { Goryeonggyo Water Level Gauging } \\
\text { Station }\end{array}$ & Sangju Weir \\
\hline 47 & & Yugok Stream & Ram Stream & Buk Stream \\
\hline
\end{tabular}


Table 1 (continued)

\begin{tabular}{|c|c|c|c|}
\hline Rank Subgroup & BOD & $\mathrm{TP}$ & TNP \\
\hline 48 & Uiryeong Stream & Haman Changnyeong Weir & $\begin{array}{l}\text { Goryeonggyo Water Level Gauging } \\
\text { Station }\end{array}$ \\
\hline 49 & Milyang River ${ }^{\mathrm{a}}$ & Yugok Stream & Shindeung Stream \\
\hline 50 & Upstream of the Nam River Dam & Seokgyo Stream & Shinban Stream \\
\hline 51 & Buk Stream & Shindeung Stream & Gangjeong Goryeong Weir \\
\hline 52 & Shinban Stream & Upstream of the Seo Stream & Yugok Stream \\
\hline 53 & Nam Stream & Palgeo Stream & Upstream of the Naeseong Stream ${ }^{a}$ \\
\hline 54 & Seongju Water Level Gauging Station & Before Merging of the Wondong Stream & Ram Stream \\
\hline 55 & Hwangji Stream & Yecheon Water Level Gauging Station & Nakhwaam Stream \\
\hline 56 & Downstream of the Byeongseong Stream ${ }^{\mathrm{a}}$ & Upstream of the Nam River Dam & Yang Stream \\
\hline 57 & Han Stream & Dongchon Water Level Gauging Station ${ }^{\mathrm{a}}$ & Seokgyo Stream \\
\hline 58 & Seokgyo Stream & Beginning of the Geumho River & Downstream of the Ian Stream \\
\hline 59 & Ram Stream & Cheongtong Stream ${ }^{\mathrm{a}}$ & Beginning of the Geumho River \\
\hline
\end{tabular}

a Those are basins of the Nakdong River watershed reported by the MOE and KECO

$1.7 \%$ of the total area and were mainly found in the basins of the Byeongseong Stream, Yeong and Geumho rivers, and downstream of the Nakdong River. The average annual rainfall indicated an approximately $100 \mathrm{~mm}$ increase from the past $(1209 \mathrm{~mm})$ to the future $(1306 \mathrm{~mm})$ while there was almost no difference in the average annual rainfall between RCP 2.6 $(1305.6 \mathrm{~mm})$ and RCP $8.5(1306.8 \mathrm{~mm})$ scenarios. The rainfall amount was high in the basins of the Naeseong Stream and downstream of the Nakdong River including the Nam River, both in the past and the future.

\section{Identification of critical source areas}

The comprehensive analysis results of the above nine factors showed that those basins that are on or adjacent to the Nakdong River mainstream were mainly identified as CSAs in high need of NPS pollution management both in the present and the future (Fig. 3). The top 20\% CSAs were mainly found in the mid- and downstream areas of the Nakdong River.

Based on the past rainfall data, the CSA results showed large agreements with respect to the spatial distributions of BOD, TP, and TNP (Fig. 3a and Table 1). The rankings of CSAs did not largely agree among BOD, TP, and TNP, but their subgroups indicated similar spatial distributions. Particularly, the basins of level 1 were the same over $80 \%$ among BOD, TP, and TNP. As the basins that are on the Nakdong River mainstream, five same basins were identified as level 1: Chilgok Weir, Before Merging of the Milyang River, Gupo Water Level Gauging Station, Nakdong River Estuary Bank, and West Nakdong River. As the basins that are adjacent to the Nakdong River mainstream, eleven tributary basins were identified as level 1: the basins of the Geumho and Nam rivers (Jincheon Stream, Downstream of the Shin Stream, Downstream, and Midstream of the Geumho River, and After Merging of the Banseong Stream) and downstream of the Nakdong River (Masuwon Water Level Gauging Station, Gyeseong Stream, Jucheon River, Hwapo Stream, Downstream of the Yangsan Stream, and Joman River). Eight of the 16 basins were revealed as important CSAs in high need of NPS pollution management, with insignificant differences even in the rankings among BOD, TN, and TNP: Joman River, Jincheon Stream, Hwapo Stream, Nakdong River Estuary Bank, West Nakdong River, Downstream of the Shin Stream, and Downstream and Midstream of the Geumho River. Many basins of the Geumho and Nam rivers were determined to be CSAs, indicating the significance of NPS pollution
Table 3 Top $10 \%$ basins in agreement with the present CSA results based on the LDC analysis

\begin{tabular}{|c|c|}
\hline Variable & Basin name \\
\hline BOD & $\begin{array}{l}\text { Before Merging of the Wi Stream }{ }^{\mathrm{a}} \text {, Gumi Weir, After Merging of the Han Stream }{ }^{\mathrm{a}} \text {, Chilgok Weir }{ }^{\mathrm{a}} \text {, } \\
\text { Gangjeong Goryeong Weir, Masuwon Water Level Gauging Station }{ }^{\mathrm{a}} \text {, Before Merging of the } \\
\text { Yeongcheon River }{ }^{\mathrm{a}} \text {, Before Merging of the Milyang River }{ }^{\mathrm{a}}, \text { Hwapo Stream }^{\mathrm{a}}\end{array}$ \\
\hline $\mathrm{TP}$ & $\begin{array}{l}\text { Okgye Stream }{ }^{\mathrm{a}} \text {, Geum Stream, After Merging of the Han Stream, Chilgok Weir }{ }^{\mathrm{a}} \text {, Masuwon Water } \\
\text { Level Gauging Station }{ }^{\mathrm{a}} \text {, Gyeseong Stream }{ }^{\mathrm{a}} \text {, Before Merging of the Milyang River }{ }^{\mathrm{a}} \text {, Hwapo } \\
\text { Stream }^{\mathrm{a}}\end{array}$ \\
\hline
\end{tabular}

${ }^{\text {a }}$ The basins belong to the level 1 subgroup of the present CSAs 


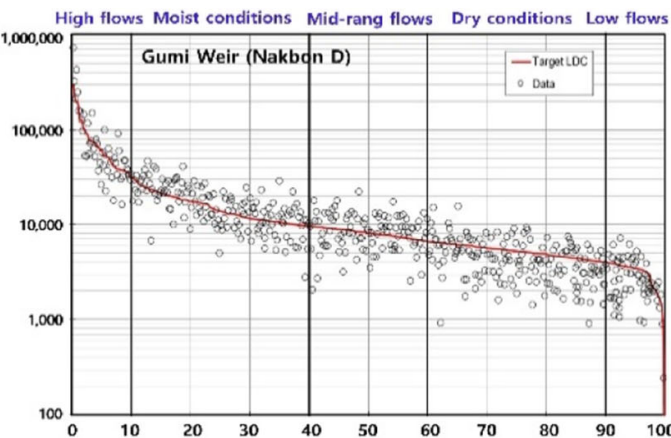

High flows Maist conditions Mid-rang flows Dry conditions Low flows
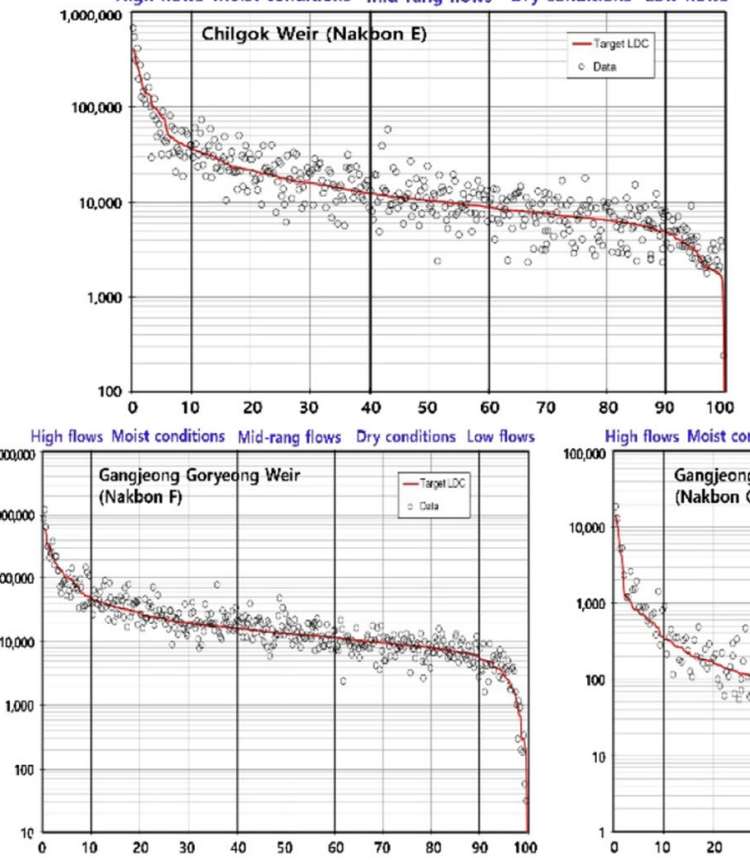

High flows Moist conditions Mid-rang flows Dry conditions Low flows

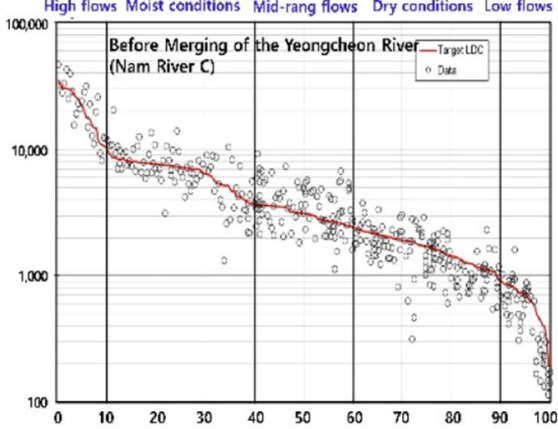

High flows Moist conditions Mid-rang flows Dry conditions Low flows
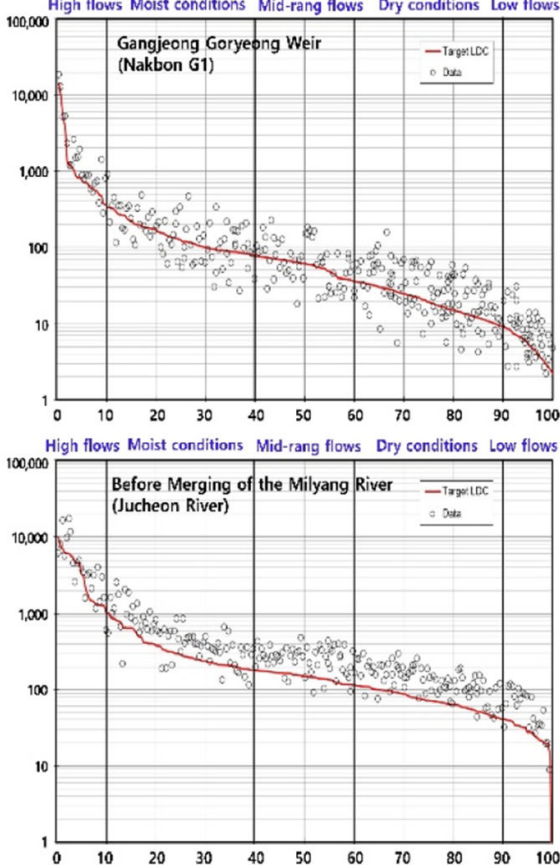

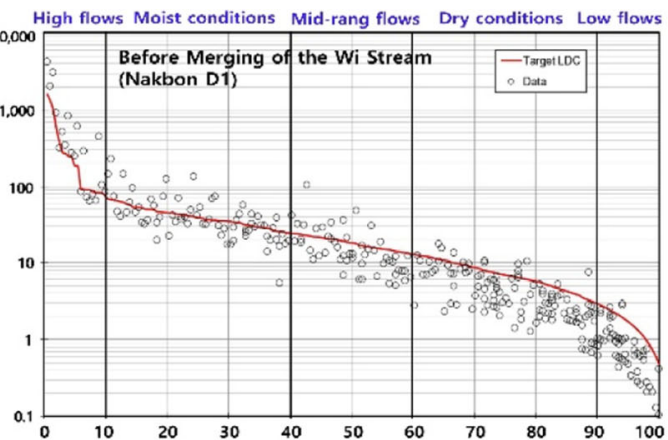

High flows Moist conditions Mid-rang flows Dry conditions Low flows
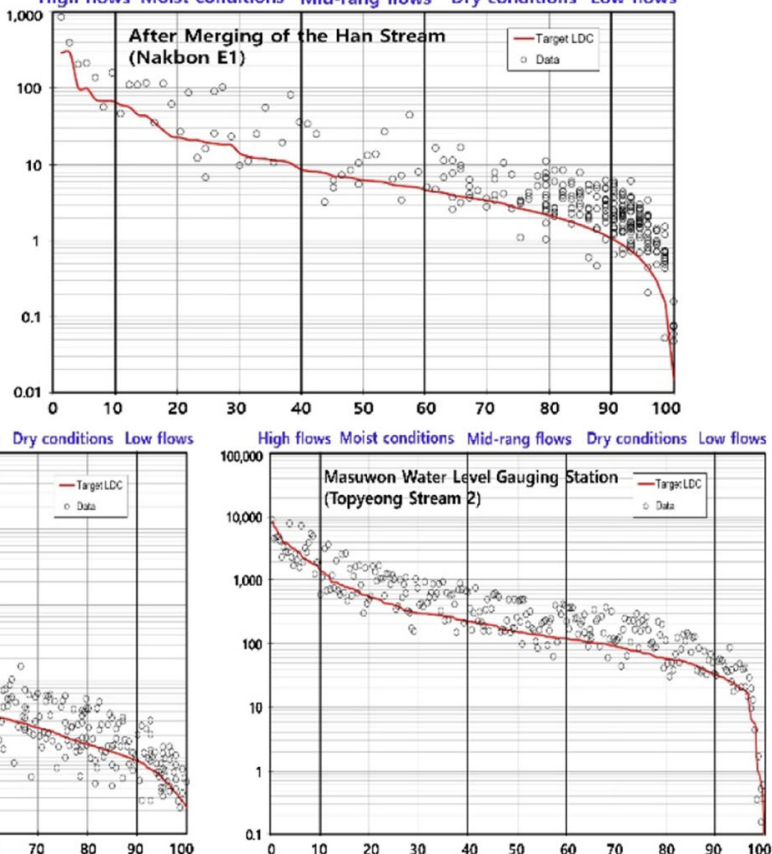

High flows Moist conditions Mid-rang flows Dry conditions Low flows

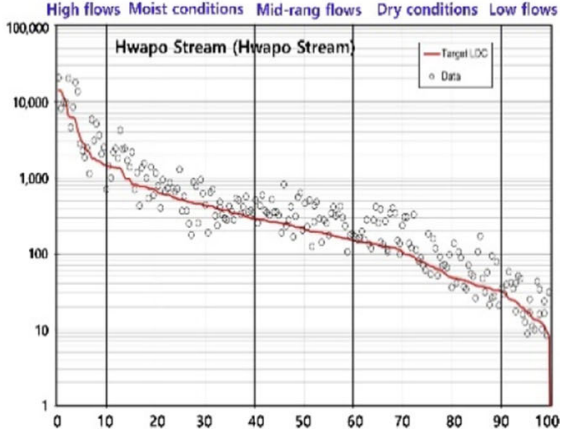

(a) BOD

Fig. 4 LDC results for the top $10 \%$ basins in agreement with the present CSAs. a BOD and $\mathbf{b}$ TP. The brackets in the figures represent the names of the Korean TMDL monitoring stations of each basin. The $x$ - and $y$-axes represent the flow duration interval (\%) and load (kg/day), respectively

management. The basins of the Naeseong and Gam streams were identified to be CSAs in TP but barely in BOD.

The results of the CSA identification based on the future rainfall data (both RCP 2.6 and RCP 8.5) showed similar spatial patterns to those based on the past rainfall data (Fig. 3b, c and Appendix Table 2). The CSAs based on the present and the future thus showed $>90 \%$ agreement with respect to the spatial distributions of all variables. In particular, the CSAs of level 1 rarely differed between the present and the future. The CSAs of the two future scenarios indicated $98 \%$ agreement with respect to all variables. The spatial distributions of the subgroups of the two future scenarios showed $>85 \%$ agreement and $100 \%$ in level 1 . The CSA rankings of 

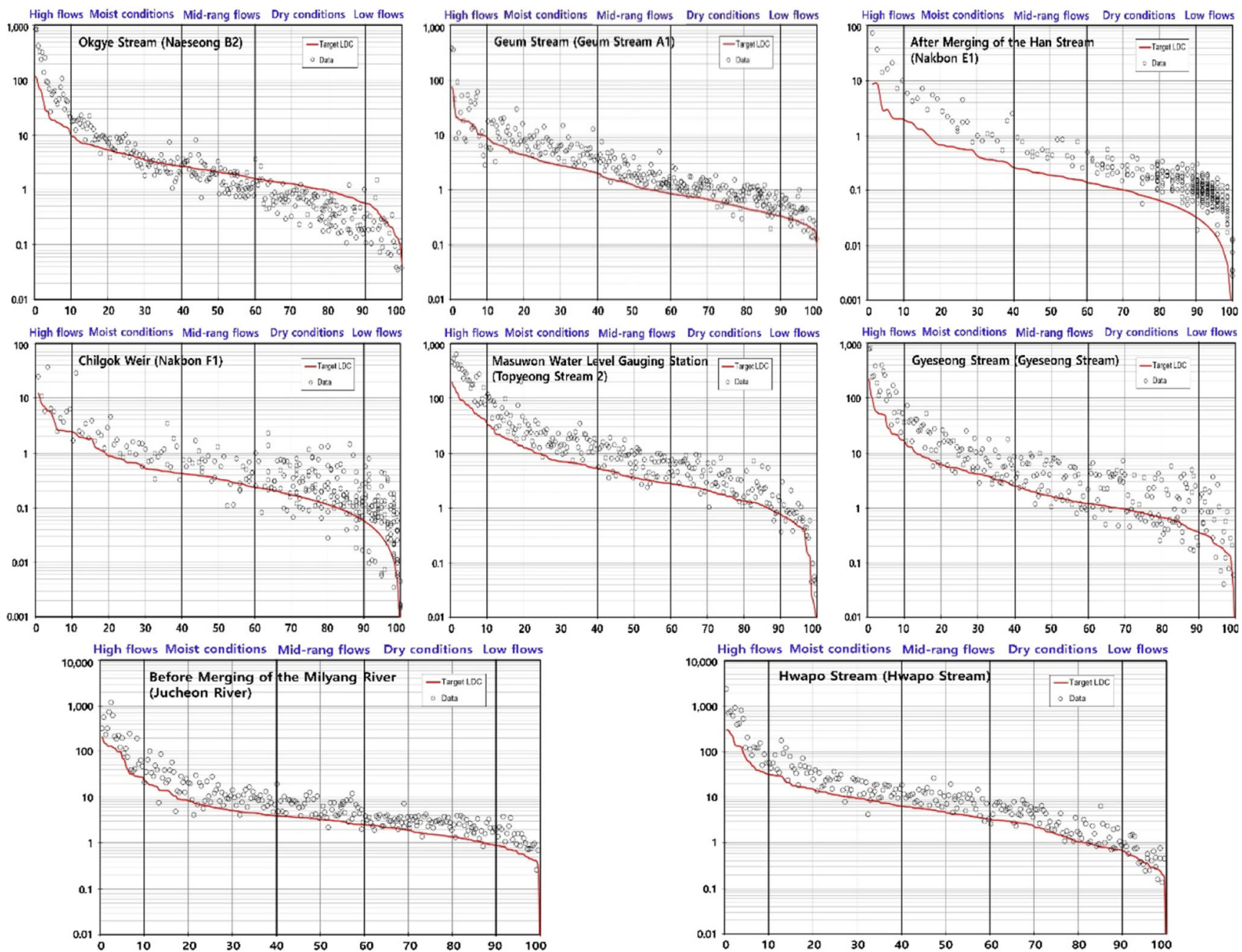

(b) TP

Fig. 4 (continued)

level 1 of the future scenarios even showed $>80 \%$ agreement.

\section{Load duration curve analysis results}

Based on the LDC analysis, the target water quality was not met in the high flow and moist condition intervals at many Korean TMDL monitoring stations. Regarding BOD and TP, 27 and 14 and 75 and 32 monitoring stations did not meet the target water quality in the high flow and moist condition intervals, respectively. More monitoring stations were found in TP, closely related to NPS pollution. The basins including those monitoring stations fairly agreed with the present CSA results. Regarding BOD and TP, $43 \%$ and $67 \%$ and $43 \%$ and $54 \%$ of the basins corresponded to the identified CSAs in the high flow and moist condition intervals, respectively. The top $10 \%$ basins were mostly included in the present CSA results, especially level 1 (Table 2). They showed the results that did not largely satisfy the target water quality in the high flow and moist condition intervals (Fig. 4). Regarding BOD, nine of the top $10 \%$ basins were in agreement with the identified CSAs and seven basins, excluding the Gumi Weir and Gangjeong Goryeong Weir, were in level 1, indicating the high need of NPS pollution management. Regarding TP, eight of the top $10 \%$ basins corresponded with the identified CSAs and six basins were in level 1, except for the Geum Stream and After Merging of the Han Stream. In particular, four basins (Chilgok Weir, Masuwon Water Level Gauging Station, Before Merging of the Milyang River, and Hwapo Stream) were in level 1 regarding both BOD and TP, indicating areas in high need of NPS pollution management.

\section{Analysis of identified critical source area results}

The present CSAs identified in this study showed the reliability of the results as including many basins of the Nakdong 
River watershed reported by the MOE and KECO. That is, the identified CSAs included 21 and 12 basins in the top 30\% and level 1 for BOD, respectively, as well as 24 and 14 and 23 and 13 basins for TP and TNP, respectively (Table 1). In level 1, the basins accounted for more than $60 \%$. In addition, the LDC analysis results showed that the basins not meeting the target water quality fairly corresponded to the present CSAs and the top $10 \%$ basins were mostly included in level 1 . These results demonstrated that the identified CSAs represented the areas vulnerable to NPS pollution in the Nakdong River watershed and CSAs of level 1 should be prioritized in NPS pollution management.

The Nakdong River watershed includes urban and rural areas along the river and mainly major cities and large agricultural areas and tributaries in the mid- and downstream areas. The watershed characteristics can explain why the basins that are on or adjacent to the Nakdong River mainstream were identified as CSAs and highly ranked basins were concentrated in the midand especially downstream areas. The CSAs of level 1 mentioned in the "Identification of critical source areas" section are all located in the downstream areas, except for the Chilgok Weir basin and the basins of the Geumho River. They are generally areas with high imperviousness due to urban and greenhouse areas, are significantly affected by rainfall, and have clay loam soils, leading to high surface runoff. In addition, the downstream areas are prone to pollutant accumulation due to low flow velocity and gentle slope. These characteristics seemed to result in the high-ranking CSAs in the downstream areas. On the other hand, in the case of the Chilgok Weir basin toward the upstream areas, the main reasons seemed to be a high ratio of urban areas and inflow of highly polluted tributaries due to nearby large industrial complexes and livestock and agricultural activities. In particular, the high ranking of the basin was possibly due to the artificial control of flow by the Chilgok weir. Seo et al. (2019b) who examined changes in coliform bacteria at the weir stations of the Nakdong River reported a drastic increase in the coliform bacteria at the Chilgok weir station for the same reason.

The Nam and Geumho rivers are tributaries of the Nakdong River whose lengths and drainage areas are first and second, respectively, in the Nakdong River watershed. Water quality in these tributaries are generally poor, compared to other tributaries (Table 3). The Nam River subbasin has widely distributed greenhouses along the river and a high ratio of urban and agricultural areas in the upstream areas. Kim et al. (2014) and Yu et al. (2012) reported high levels of pollution in the Nam River due to NPS pollutants from livestock farms and urban and industrial areas. A number of CSAs in this subbasin was possibly because of livestock manure and fertilizer,

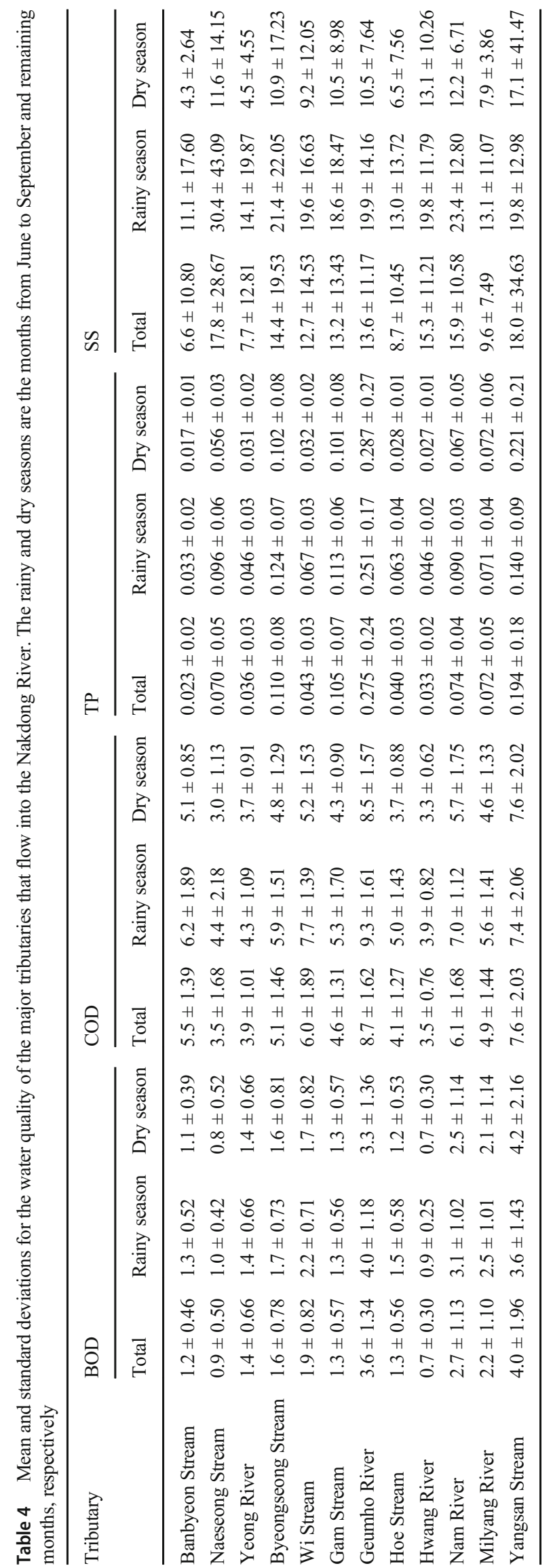


Table 5 Impact of each factor on the identification of CSAs (in \%). The value represents the ratio of the same basins identified as CSAs before and after the elimination of each factor and the range of the value refers to the results based on BOD, TP, and TNP

\begin{tabular}{|c|c|c|c|c|c|c|c|c|c|}
\hline Rank & - Factor $1^{\mathrm{a}}$ & -Factor 2 & -Factor 3 & -Factor 4 & -Factor 5 & -Factor 6 & -Factor 7 & -Factor 8 & -Factor 9 \\
\hline Total (top 30\%) & 89.8-94.9 & $98.3-100.0$ & $88.1-93.2$ & $89.8-91.5$ & $84.7-88.1$ & $89.8-93.2$ & 88.1 & $94.9-96.6$ & $74.6-84.7$ \\
\hline Level 1 & $90.0-95.0$ & $95.0-100.0$ & $90.0-95.0$ & $85.0-90.0$ & $90.0-95.0$ & $85.0-90.0$ & $90.0-95.0$ & $90.0-95.0$ & $80.0-85.0$ \\
\hline Level 2 & $68.4-84.2$ & $89.5-100.0$ & $68.4-84.2$ & $57.9-73.7$ & $73.7-78.9$ & $68.4-73.7$ & $57.9-78.9$ & 84.2 & $26.3-36.8$ \\
\hline Level 3 & $55.0-65.0$ & 95.0 & $55.0-65.0$ & $50.0-60.0$ & $45.0-60.0$ & $55.0-60.0$ & $35.0-55.0$ & $75.0-90.0$ & $10.0-20.0$ \\
\hline
\end{tabular}

a “_” indicates the elimination of the factor, with (1) NPS pollution load per unit area, (2) residential/industrial NPS pollution load per unit area, (3) mean water quality, (4) excess percentage of water quality standards, (5) water quality index, (6) impervious area, (7) soil slope, (8) topsoil type, and (9) rainfall

untreated and unknown water from residential and industrial areas, and high proportions of impervious areas. The Geumho River subbasin also had many CSAs probably due to areas with high ratios of urban such as Daegu, one of the major metropolitan cities in South Korea. Kim et al. (2012) and Niraula et al. (2013) reported a high potential impact of urban areas on NPS pollution. The Omok Stream basin was the only agricultural CSA identified in the Geumho River subbasin, which seemed due to agricultural activities in an exceptionally high ratio of agricultural areas (ranked 2nd among all 195 basins). The Geumho River subbasin had a higher ratio of clay loam soils than the other subbasins (Fig. 2h), which could be one of the reasons for many CSAs in this subbasin. Jung et al. (2016) and Seo et al. (2019b) reported that dense industrial complexes and wastewater treatment plants and agricultural areas in this subbasin might have negative impacts on water quality of the Geumho River.

However, rainfall is, above all else, an influential factor inducing NPS pollution (Huang et al. 2015), which we found in good agreement in this study. The water quality of major tributaries of the Nakdong River presented the impact of rainfall, generally indicating higher concentrations and wider variations during rainy seasons than dry seasons (Table 3). The relative significance of individual factors that are considered in identifying CSAs was evaluated by comparing CSA result considering the full nine factors with nine subsets of CSA results considering only eight factors. Among those subsets, the CSA result considering eight factors but the rainfall factor was excluded presented the largest difference (Table 4). In addition, as large amounts of rainfall occurred in the mid- and downstream areas of the Nakdong River as well as in the Naeseong Stream subbasin (Fig. 2i), the high-ranking CSAs showing up in the mid- and downstream areas indicated a good agreement between the distribution of CSAs and the spatial patterns of rainfall. Regarding TP, several basins of the Naeseong Stream subbasin were identified as CSAs, similar to the rainfall distribution. The impact of rainfall in the identification of CSAs also provided a clue on future CSAs such as the Byeongseong Stream, Andong Dam, and Downstream of the Andong Dam subbasins. These subbasins will be in greater needs for NPS management given that they are expected to get $15-18 \%$ increases in rainfall in the future.

Doppler et al. (2014) reported that the CSAs of NPS pollution could vary depending on rainfall. The rainfall factor largely affected the identification of CSAs as described above. However, it did not cause large discrepancies in the spatial distribution of CSAs among the present and two future (RCP 2.6 and RCP 8.5) scenarios. It seemed because there was little difference in rainfall among those scenarios. The future scenarios do not provide detailed rainfall information, such as duration and intensity; thus, the amount of rainfall was only used in this study to identify CSAs. More research should be carried out on statistically relating CSA identification and various future climatic properties to properly identify future NPS pollution. The results of this study indicated that the present CSAs of NPS pollution will likely be the CSAs of NPS pollution in the future. This means that (1) a focus should be placed on the present CSAs in preparation for future NPS pollution; (2) extra efforts should be made to manage NPS pollution in highly ranked CSAs (level 1) in both the present and the future; and (3) the CSAs identified only in the future scenarios should not be overlooked to prevent uncontrolled NPS pollution in these areas in the future.

\section{Conclusions}

Identification of CSAs is the first step toward an effective management of NPS pollution. In this study, CSAs that are in need of NPS pollution management in the present and the future were identified in the Nakdong River watershed, South Korea. The identified CSAs were mainly distributed along the Nakdong River mainstream. Areas in the mid- and downstream of the Nakdong River were identified as CSAs in need of substantial management in both the present and the future. Particularly, differences in the distribution of CSAs between the present and the future were found insignificant. The results 
demonstrated that future management of NPS pollution should be planned out based on the present distribution of CSAs regardless of the impact of climate change in the Nakdong River watershed. However, it is obviously important to consider the impact of climate change in predicting and preparing for future NPS pollution. A variety of research related to climate change is needed to allow an effective management of NPS pollution in the future. It is also necessary to establish step-by-step local strategies of NPS pollution management under climate change, such as investigating major pollutants, setting up goals, and suggesting measures for identified CSAs under changing climate conditions. Such studies will provide regional policy makers with information on NPS pollution management, facilitating the proper management of regions in the present and the future.

\section{Appendix}

Table 2 Rankings of CSAs (basins) for each variable in the future based on (a) RCP 2.6 and (b) RCP 8.5

\begin{tabular}{|c|c|c|c|c|}
\hline \multirow[t]{2}{*}{ Rank } & \multirow[t]{2}{*}{ Subgroup } & \multicolumn{3}{|l|}{ (a) Based on future rainfall data (RCP 2.6) } \\
\hline & & BOD & $\mathrm{TP}$ & TNP \\
\hline 1 & Level 1 & Joman River & Joman River & Joman River \\
\hline 2 & & Jincheon Stream & Jincheon Stream & Jincheon Stream \\
\hline 3 & & West Nakdong River & Hwapo Stream & Hwapo Stream \\
\hline 4 & & Hwapo Stream & West Nakdong River & West Nakdong River \\
\hline 5 & & Nakdong River Estuary Bank & Nakdong River Estuary Bank & Nakdong River Estuary Bank \\
\hline 6 & & Downstream of the Shin Stream & Downstream of the Shin Stream & Downstream of the Shin Stream \\
\hline 7 & & Downstream of the Geumho River & Downstream of the Geumho River & Downstream of the Geumho River \\
\hline 8 & & Gupo Water Level Gauging Station & After Merging of the Banseong Stream & Gupo Water Level Gauging Station \\
\hline 9 & & Midstream of the Geumho River & Gyeseong Stream & Midstream of the Geumho River \\
\hline 10 & & Before Merging of the Milyang River & Masuwon Water Level Gauging Station & Before Merging of the Milyang River \\
\hline 11 & & Downstream of the Yangsan Stream & Midstream of the Geumho River & Masuwon Water Level Gauging Station \\
\hline 12 & & After Merging of the Banseong Stream & Chilgok Weir & Chilgok Weir \\
\hline 13 & & Masuwon Water Level Gauging Station & Gupo Water Level Gauging Station & Jucheon River \\
\hline 14 & & Chilgok Weir & Downstream of the Yangsan Stream & After Merging of the Banseong Stream \\
\hline 15 & & $\begin{array}{l}\text { Before Merging of the Yeongcheon } \\
\text { River }\end{array}$ & Before Merging of the Milyang River & Gyeseong Stream \\
\hline 16 & & Before Merging of the Wi Stream & $\begin{array}{l}\text { Jeokpogyo Water Level Gauging } \\
\text { Station }\end{array}$ & Before Merging of the Wi Stream \\
\hline 17 & & After Merging of the Han Stream & Downstream of the Seo Stream & Downstream of the Yangsan Stream \\
\hline 18 & & Gyeseong Stream & Upstream of the Byeongseong Stream & Upstream of the Byeongseong Stream \\
\hline 19 & & Jucheon River & Okgye Stream & Before Merging of the Yeongcheon River \\
\hline 20 & & Wolchon Water Level Gauging Station & Downstream of the Gam Stream & Wolchon Water Level Gauging Station \\
\hline 21 & Level 2 & Yeongcheon River & $\begin{array}{l}\text { Before Merging of the Yeongcheon } \\
\text { River }\end{array}$ & Jeokpogyo Water Level Gauging Station \\
\hline 22 & & Downstream of the Seo Stream & After Merging of the Han Stream & Yeongcheon River \\
\hline 23 & & Gwangryeo Stream & Yeongcheon River & Omok Stream \\
\hline 24 & & Upstream of the Byeongseong Stream & Before Merging of the Wi Stream & Downstream of the Seo Stream \\
\hline 25 & & $\begin{array}{l}\text { Jeokpogyo Water Level Gauging } \\
\text { Station }\end{array}$ & Omok Stream & After Merging of the Han Stream \\
\hline 26 & & Sangju Weir & $\begin{array}{l}\text { Downstream of the Byeongseong } \\
\text { Stream }\end{array}$ & Okgye Stream \\
\hline 27 & & Haman Changnyeong Weir & Jucheon River & Downstream of the Byeongseong Stream \\
\hline 28 & & Omok Stream & Wolchon Water Level Gauging Station & Downstream of the Gam Stream \\
\hline 29 & & Cha Stream & Geum Stream & Changnyeong Hapcheon Weir \\
\hline 30 & & Gumi Weir & Gwangryeo Stream & Gwangryeo Stream \\
\hline 31 & & Before Merging of the Wondong & Upstream of the Naeseong Stream & Cha Stream \\
\hline
\end{tabular}


Table 2 (continued)

Rank Subgroup
Changnyeong Hapcheon Weir

Hyeonpung Water Level Gauging Station

Milyang River

Downstream of the Nam River

Haman Stream

Buk Stream

Jeongam Water Level Gauging Station

Level 3 Downstream of the Gam Stream

Downstream of the Byeongseong Stream

Banseong Stream

Before Merging of the Haman Stream

Upstream of the Yangsan Stream

Downstream of the Ian Stream

Upstream of the Naeseong Stream

Gangjeong Goryeong Weir

Goryeonggyo Water Level Gauging Station

Palgeo Stream

Yugok Stream

Uiryeong Stream

Han Stream

Nam River Dam

Seongju Water Level Gauging Station

Upstream of the Ian Stream

Andong Dam

Upstream of the Nam River Dam

Dongchon Water Level Gauging Station

Imhaejin Water Level Gauging Station
After Merging of the Shin Stream

Cha Stream

Buk Stream

Downstream of the Nam River

Nakhwaam Stream

Upstream of the Yangsan Stream

Gimcheon Water Level Gauging Station

Jukgye Stream

Haman Changnyeong Weir

Banseong Stream

Changnyeong Hapcheon Weir

Jeongam Water Level Gauging Station

Haman Stream

Seongju Water Level Gauging Station

Before Merging of the Wondong Stream

Milyang River

Upstream of the Seo Stream

Sangju Weir

Yecheon Water Level Gauging Station Ram Stream

Yugok Stream

Hyeonpung Water Level Gauging Station

Seokgyo Stream

Nam River Dam

Jikjisa Stream

After Merging of the Shin Stream

Upstream of the Han Stream

Beginning of the Geumho River

Goryeonggyo Water Level Gauging Station

(b) Based on future rainfall data (RCP 8.5)

BOD

Level 1 Joman River

Jincheon Stream

West Nakdong River

Hwapo Stream

Nakdong River Estuary Bank

Downstream of the Shin Stream

Downstream of the Geumho River

Gupo Water Level Gauging Station

Midstream of the Geumho River

Before Merging of the Milyang River

Downstream of the Yangsan Stream

After Merging of the Banseong Stream

Masuwon Water Level Gauging Station

Chilgok Weir
$\mathrm{TP}$

Joman River

Jincheon Stream

Hwapo Stream

West Nakdong River

Nakdong River Estuary Bank

Downstream of the Shin Stream

Downstream of the Geumho River

After Merging of the Banseong Stream

Gyeseong Stream

Masuwon Water Level Gauging Station

Midstream of the Geumho River

Chilgok Weir

Gupo Water Level Gauging Station

Downstream of the Yangsan Stream
Before Merging of the Wondong Stream

Buk Stream

Sangju Weir

Geum Stream

Downstream of the Nam River

Upstream of the Naeseong Stream

Haman Changnyeong Weir

Upstream of the Yangsan Stream

Haman Stream

Milyang River

Seongju Water Level Gauging Station

Banseong Stream

After Merging of the Shin Stream

Nakhwaam Stream

Jeongam Water Level Gauging Station

Gumi Weir

Upstream of the Nam River Dam

Hyeonpung Water Level Gauging Station

Palgeo Stream

Wi Stream

Downstream of the Ian Stream

Jukgye Stream

Dongchon Water Level Gauging Station

Downstream of the Andong Dam Balancing Reservoir

Nam River Dam

Yugok Stream

Shinban Stream

Beginning of the Geumho River

TNP

Joman River

Jincheon Stream

Hwapo Stream

West Nakdong River

Nakdong River Estuary Bank

Downstream of the Shin Stream

Downstream of the Geumho River

Gupo Water Level Gauging Station

Midstream of the Geumho River

Before Merging of the Milyang River

Masuwon Water Level Gauging Station

Jucheon River

Chilgok Weir

After Merging of the Banseong Stream 
Table 2 (continued)

\begin{tabular}{|c|c|c|c|c|}
\hline 15 & & $\begin{array}{l}\text { Before Merging of the Yeongcheon } \\
\text { River }\end{array}$ & $\begin{array}{l}\text { Jeokpogyo Water Level Gauging } \\
\text { Station }\end{array}$ & Gyeseong Stream \\
\hline 16 & & After Merging of the Han Stream & Before Merging of the Milyang River & Downstream of the Yangsan Stream \\
\hline 17 & & Gyeseong Stream & Downstream of the Seo Stream & Before Merging of the Wi Stream \\
\hline 18 & & Jucheon River & Upstream of the Byeongseong Stream & Upstream of the Byeongseong Stream \\
\hline 19 & & Before Merging of the Wi Stream & Okgye Stream & Before Merging of the Yeongcheon River \\
\hline 20 & & Wolchon Water Level Gauging Station & Downstream of the Gam Stream & Wolchon Water Level Gauging Station \\
\hline 21 & Level 2 & Yeongcheon River & $\begin{array}{l}\text { Before Merging of the Yeongcheon } \\
\text { River }\end{array}$ & Jeokpogyo Water Level Gauging Station \\
\hline 22 & & Gwangryeo Stream & After Merging of the Han Stream & Yeongcheon River \\
\hline 23 & & $\begin{array}{l}\text { Jeokpogyo Water Level Gauging } \\
\text { Station }\end{array}$ & Yeongcheon River & Omok Stream \\
\hline 24 & & Downstream of the Seo Stream & Omok Stream & After Merging of the Han Stream \\
\hline 25 & & Upstream of the Byeongseong Stream & Jucheon River & Downstream of the Seo Stream \\
\hline 26 & & Sangju Weir & Wolchon Water Level Gauging Station & Changnyeong Hapcheon Weir \\
\hline 27 & & Haman Changnyeong Weir & Gwangryeo Stream & Gwangryeo Stream \\
\hline 28 & & Cha Stream & Before Merging of the Wi Stream & Okgye Stream \\
\hline 29 & & Omok Stream & $\begin{array}{l}\text { Downstream of the Byeongseong } \\
\text { Stream }\end{array}$ & Cha Stream \\
\hline 30 & & Changnyeong Hapcheon Weir & Cha Stream & Downstream of the Gam Stream \\
\hline 31 & & $\begin{array}{l}\text { Before Merging of the Wondong } \\
\text { Stream }\end{array}$ & Geum Stream & Downstream of the Byeongseong Stream \\
\hline 32 & & $\begin{array}{l}\text { Hyeonpung Water Level Gauging } \\
\text { Station }\end{array}$ & Downstream of the Nam River & Before Merging of the Wondong Stream \\
\hline 33 & & Gumi Weir & Upstream of the Naeseong Stream & Downstream of the Nam River \\
\hline 34 & & Downstream of the Nam River & Buk Stream & Buk Stream \\
\hline 35 & & Haman Stream & Upstream of the Yangsan Stream & Geum Stream \\
\hline 36 & & Milyang River & $\begin{array}{l}\text { Gimcheon Water Level Gauging } \\
\text { Station }\end{array}$ & Sangju Weir \\
\hline 37 & & After Merging of the Shin Stream & Nakhwaam Stream & Haman Changnyeong Weir \\
\hline 38 & & Jeongam Water Level Gauging Station & Banseong Stream & Haman Stream \\
\hline 39 & & Banseong Stream & Changnyeong Hapcheon Weir & Upstream of the Yangsan Stream \\
\hline 40 & Level 3 & Before Merging of the Haman Stream & Haman Changnyeong Weir & Upstream of the Naeseong Stream \\
\hline 41 & & Downstream of the Gam Stream & Jeongam Water Level Gauging Station & Banseong Stream \\
\hline 42 & & Buk Stream & Haman Stream & After Merging of the Shin Stream \\
\hline 43 & & Upstream of the Yangsan Stream & Jukgye Stream & Seongju Water Level Gauging Station \\
\hline 44 & & $\begin{array}{l}\text { Downstream of the Byeongseong } \\
\text { Stream }\end{array}$ & Seongju Water Level Gauging Station & Milyang River \\
\hline 45 & & Downstream of the Ian Stream & $\begin{array}{l}\text { Before Merging of the Wondong } \\
\text { Stream }\end{array}$ & Jeongam Water Level Gauging Station \\
\hline 46 & & Gangjeong Goryeong Weir & Milyang River & Hyeonpung Water Level Gauging Station \\
\hline 47 & & $\begin{array}{l}\text { Goryeonggyo Water Level Gauging } \\
\text { Station }\end{array}$ & Ram Stream & Upstream of the Nam River Dam \\
\hline 48 & & Palgeo Stream & Yugok Stream & Palgeo Stream \\
\hline 49 & & Yugok Stream & Seokgyo Stream & Nakhwaam Stream \\
\hline 50 & & Uiryeong Stream & Upstream of the Seo Stream & Gumi Weir \\
\hline 51 & & Upstream of the Naeseong Stream & $\begin{array}{l}\text { Hyeonpung Water Level Gauging } \\
\text { Station }\end{array}$ & Dongchon Water Level Gauging Station \\
\hline 52 & & Han Stream & Sangju Weir & $\begin{array}{l}\text { Downstream of the Andong Dam Balancing } \\
\text { Reservoir }\end{array}$ \\
\hline 53 & & Seongju Water Level Gauging Station & Yecheon Water Level Gauging Station & Yugok Stream \\
\hline 54 & & Andong Dam & After Merging of the Shin Stream & Shinban Stream \\
\hline 55 & & Upstream of the Nam River Dam & Jikjisa Stream & Downstream of the Ian Stream \\
\hline 56 & & Nam River Dam & $\begin{array}{l}\text { Goryeonggyo Water Level Gauging } \\
\text { Station }\end{array}$ & Nam River Dam \\
\hline
\end{tabular}


Table 2 (continued)

\begin{tabular}{llll}
\hline 57 & Dongchon Water Level Gauging & Nam River Dam & Seokgyo Stream \\
Station & Shinban Stream & Beginning of the Geumho River & Wi Stream \\
58 & Upstream of the Ian Stream & Gaya Stream & Beginning of the Geumho River \\
\hline 59 & &
\end{tabular}

Acknowledgements We appreciate anonymous reviewers for their comments improving the manuscript. We also thank members of the Nakdong River Environment Research Center for their assistance.

Author contribution M. Seo, J. Heo and Y. Kim contributed to the study conceptualization, data collection, and analysis. Y. Kim supervised the study. The first draft of the manuscript was written by M. Seo and all authors have read and agreed to the published version of the manuscript.

Funding This research was supported by the National Institute of Environmental Research (NIER) of the Republic of Korea with the grant number NIER-2020-05-01-002.

\section{Compliance with ethical standards}

Competing interests The authors declare that they have no conflict of interest.

Open Access This article is licensed under a Creative Commons Attribution 4.0 International License, which permits use, sharing, adaptation, distribution and reproduction in any medium or format, as long as you give appropriate credit to the original author(s) and the source, provide a link to the Creative Commons licence, and indicate if changes were made. The images or other third party material in this article are included in the article's Creative Commons licence, unless indicated otherwise in a credit line to the material. If material is not included in the article's Creative Commons licence and your intended use is not permitted by statutory regulation or exceeds the permitted use, you will need to obtain permission directly from the copyright holder. To view a copy of this licence, visit http://creativecommons.org/licenses/by/4.0/.

\section{References}

Ahn SR, Ha R, Yoon SW, Kim SJ (2014) Evaluation of future turbidity water and eutrophication in Chungju Lake by climate change using CE-QUAL-W2. J Korea Water Resour Assoc 47:145-159

Dong F, Liu Y, Wu Z, Chen Y, Guo H (2018) Identification of watershed priority management areas under water quality constraints: a simulation-optimization approach with ideal load reduction. J Hydrol 562:577-588

Doppler T, Lück A, Camenzuli L, Krauss M, Stamm C (2014) Critical source areas for herbicides can change location depending on rain events. Agric Ecosyst Environ 192:85-94

Ghebremichael LT, Veith TL, Watzin MC (2010) Determination of critical source areas for phosphorus loss: Lake Champlain basin, Vermont. T ASABE 53:1595-1604

Han JH, Lee DJ, Kang BS, Chung SW, Jang WS, Lim KJ, Kim JG (2017) Potential impacts of future extreme storm events on streamflow and sediment in Soyang-dam watershed. J Korean Soc Water Environ $33: 160-169$
Huang JJ, Lin X, Wang J, Wang H (2015) The precipitation driven correlation-based mapping method (PCM) for identifying the critical source areas of non-point source pollution. J Hydrol 524:100-110

Jang SS, Kim SJ (2017) Assessment of climate change impact on highland agricultural watershed hydrologic cycle and water quality under RCP scenarios using SWAT. J Korean Soc Agric Eng 59:41-50

Jang NJ, Kim BG, Im SH, Kim TK (2012) A study on evaluation of target region for the agricultural non-point sources management. J Korean Soc Environ Eng 34:23-31

Jang SS, Ji HS, Kim HK (2018) Identifying priority area for nonpoint source pollution management and setting up load reduction goals using the load duration curve. J Korean Soc Agric Eng 60:17-27

Jung W, Yi S, Kim G, Jeong S (2011) Watershed selection for diffuse pollution management based on flow regime alteration and water quality variation analysis. J Korean Soc Water Environ 27:228-234

Jung KY, Ahn JM, Kim KS, Lee IJ, Yang DS (2016) Evaluation of water quality characteristics and water quality improvement grade classification of Geumho River tributaries. J Environ Sci Int 25:767-787

Kal BS, Mun HS, Hong SH, Park CD, Gil HN, Park JB (2019) A study on the analysis and evaluation of vulnerability index for the management of nonpoint source in SoOak River watershed. J Korean Assoc Geogr Inf Stud 22:107-120

Kang KC, Kim JS, Won CH (2013) A study of the dynamic characteristics of water quality for the selection of non-point sources management area in Dongjin-River basin. J Korean Soc Environ Technol $14: 332-342$

Kang MJ, Rhew DH, Choi JY (2014) Policies and research trends on nonpoint source pollution management in Korea. J Environ Policy Admin 22:141-167

KECO (2018) Identification of critical source areas of agricultural nonpoint source pollution in the Nakdong River watershed. Korea Environment Corporation, Incheon

Kim TG (2014) Assessment of watershed characteristics for apprehensive area of non-point source pollution using load duration curve. J Korean Soc Environ Technol 15:1-11

Kim HT, Shin DS, Park JH, Park BK, Park JH, Lee JK, Kang MJ, Cha IK, Moon SJ (2012) Analysis of a vulnerable area about non-point pollution source and decision of control priority (Publication No 111480523-001235-01). Ministry of Environment, National Institute of Environmental Research, Incheon

Kim GH, Jung KY, Lee IJ, Lee KL, Cheon SU, Im TH, Yoon JS (2014) A study on instream flow for water quality improvement in lower watershed of Nam River dam. J Korean Soc Water Environ 30: 44-59

Kim JS, Lee JM, Na EH, Shin DS, Lee JK, Ryu JC (2019) A study on the plan for selection of prioritization management area for reduction of non-point pollution in Gwangju metropolitan city. J Environ Policy Admin 27:189-214

Lee J, Park H, Lim B, Lee C, Lee S, Lee Y (2012) A study on the selection of non-point pollution management regions with high priority order in the Yeongsan River basin. Korean J Ecol Environ 45: 347-355

Liu R, Xu F, Zhang P, Yu W, Men C (2016) Identifying non-point source critical source areas based on multi-factors at a basin scale with SWAT. J Hydrol 533:379-388

Liu Y, Engel BA, Collingsworth PD, Pijanowski BC (2017) Optimal implementation of green infrastructure practices to minimize 
influences of land use change and climate change on hydrology and water quality: case study in Spy Run Creek watershed, Indiana. Sci Total Environ 601:1400-1411

Lucci GM, McDowell RW, Condron LM (2012) Phosphorus source areas in a dairy catchment in Otago, New Zealand. Soil Res 50: $145-156$

MOE (2016a) Identification of critical source areas for nonpoint source pollution management. Ministry of Environment, Sejong

MOE (2016b) Manual for installation, operation, and management of nonpoint pollutant treatment facilities (Publication No 11 1480000-001430-01). Ministry of Environment, Sejong

Munafo M, Cecchi G, Baiocco F, Mancini L (2005) River pollution from non-point sources: a new simplified method of assessment. J Environ Manag 77:93-98

NIER (2019) Technical guidelines for Korean total maximum daily loads (Publication No 11-1480523-003731-14). National Institute of Environmental Research, Incheon

NIMR (2012) Global climate change report for the fifth IPCC assessment report 2012 - outlook on climate change for RCP 2.6/4.5/6.0/8.5(Publication No 11-1360395-000341-10). National Institute of Meteorological Research, Jeju

Niraula R, Kalin L, Wang R, Srivastava P (2012) Determining nutrient and sediment critical source areas with SWAT: effect of lumped calibration. T ASABE 55:137-147

Niraula R, Kalin L, Srivastava P, Anderson CJ (2013) Identifying critical source areas of nonpoint source pollution with SWAT and GWLF. Ecol Model 268:123-133

NRERC (2018) Long-term monitoring of the tributaries in the Nakdong River system and evaluation of the achievement of target water quality. Nakdong River Environment Research Center, Daegu

Orlikowski D, Bugey A, Périllon C, Julich S, Guégain C, Soyeux E, Matzinger A (2011) Development of a GIS method to localize critical source areas of diffuse nitrate pollution. Water Sci Technol 64: 892-898

Park S, Jeong W, Yi S, Lim B (2010) A study for the selection method of control area of nonpoint pollution source. J Korean Soc Water Environ 26:761-767

Park BK, Kang MJ, Kim EJ, Ryu JC, Kim SJ, Ahn KH, Kim HT, Park JH, Shin DS, Kim YS, Rhew DH (2013) Decision of prioritization of catchments and determination of control target for non-point source pollution management - focus on the prioritization of catchments - (Publication No 11-1480523-001686-01). Ministry of Environment, National Institute of Environmental Research, Incheon

Park BK, Chung EG, Kang MJ, Kim EJ, Ahn KH, Kim YS, Rhew DH (2015) Decision of prioritization of catchments and determination of control target for non-point source pollution management (III) (Publication No 11-1480523-002656-01). Ministry of Environment, National Institute of Environmental Research, Incheon
Park BK, Ryu JC, Na EH, Seo JY, Kim YS (2017) Study on the application of spatial-analysis of pollutants and load duration curve for efficient implementation of TMDLs. J Korean Soc Environ Eng 39: $655-663$

Renkenberger J, Montas H, Leisnham PT, Chanse V, Shirmohammadi A, Sadeghi A, Brubaker K, Rockler A, Hutson T, Lansing D (2016) Climate change impact on critical source area identification in a Maryland watershed. T ASABE 59:1803-1819

Seo MJ, Kim YS, Im TH, Lee CG, Kim SM, Yang DS, Park SJ, Park HK, Kwon HG, Jeong HG, Kim YJ, Kim HM, Kim GH, Kim JM (2019a) Adaptation of nonpoint source pollution management to climate change: a review (Publication No 11-1480523-00381701). Ministry of Environment, National Institute of Environmental Research, Incheon

Seo M, Lee H, Kim Y (2019b) Relationship between coliform bacteria and water quality factors at weir stations in the Nakdong River, South Korea. Water 11:1171

Shang X, Wang X, Zhang D, Chen W, Chen X, Kong H (2012) An improved SWAT-based computational framework for identifying critical source areas for agricultural pollution at the lake basin scale. Ecol Model 226:1-10

Shin JB, Park SW, Kim HK, Choi RY (2007) Selecting target sites for non-point source pollution management using analytic hierarchy process. J Korean Soc Agric Eng 49:79-88

Shrestha NK, Allataifeh N, Rudra R, Daggupati P, Goel PK, Dickinson T (2019) Identifying threshold storm events and quantifying potential impacts of climate change on sediment yield in a small upland agricultural watershed of Ontario. Hydrol Process 33:920-931

US EPA (2007) An approach for using load duration curves in the development of TMDLs (EPA 841-B-07-006). US Environmental Protection Agency, Washington DC

Winchell MF, Folle S, Meals D, Moore J, Srinivasan R, Howe EA (2015) Using SWAT for sub-field identification of phosphorus critical source areas in a saturation excess runoff region. Hydrol Sci J 60: 844-862

Yi HS, Choi KS, Chong SA, Lee SJ (2015) Assessment of apprehensive area of non-point source pollution using watershed model application in Juam Dam. J Korean Soc Environ Eng 37:551-557

Yu JJ, Shin SH, Yoon YS, Kang DK (2012) Water quality prediction and forecast of pollution source in Namgang mid-watershed each reduction scenario. J Environ Impact Assess 21:543-552

Zhuang Y, Zhang L, Du Y, Yang W, Wang L, Cai X (2016) Identification of critical source areas for nonpoint source pollution in the Danjiangkou reservoir basin, China. Lake Reservoir Manag 32: 341-352

Publisher's note Springer Nature remains neutral with regard to jurisdictional claims in published maps and institutional affiliations. 